\title{
Density-dependent, landscape, and climate effects on spawning distribution of walleye pollock Theragra chalcogramma
}

\author{
Nathan M. Bacheler ${ }^{1,4, *}$, Kevin M. Bailey ${ }^{2}$, Lorenzo Ciannelli ${ }^{1}$, Valerio Bartolino ${ }^{1}$, \\ Kung-Sik Chan ${ }^{3}$ \\ ${ }^{1}$ College of Oceanic and Atmospheric Sciences, 104 COAS Administration Building, Oregon State University, Corvallis, \\ Oregon 97331, USA \\ ${ }^{2}$ Alaska Fisheries Science Center, NOAA-Fisheries, Seattle, Washington 98115, USA \\ ${ }^{3}$ Department of Statistics and Actuarial Science, University of Iowa, Iowa City, Iowa 52242, USA \\ ${ }^{4}$ Present address: University of Wisconsin Green Bay, Natural and Applied Sciences ES 317, 2420 Nicolet Drive, Green Bay, \\ Wisconsin 54311, USA
}

ABSTRACT: Little is known about the ways in which density-dependent and density-independent factors influence the spatial dynamics of fish spawning, despite their importance for egg and larval development, survival, and, ultimately, recruitment. Using 2 novel approaches, we related the spatial and temporal patterns of $28 \mathrm{yr}$ of walleye pollock Theragra chalcogramma egg data in Shelikof Strait, Alaska, USA, to density-dependent, landscape, and climate effects. First, we used a spatially explicit variable coefficient generalized additive model (GAM) to show that spawning biomass, water temperature, and ocean transport each had unique spatial effects on walleye pollock egg density. Specifically, increased spawning biomass had a positive effect on egg density at the periphery of the core spawning area, inferring spawning area expansion at high spawning biomass and contraction at low levels. Moreover, increased Shelikof Strait transport caused pollock egg density to increase at the downstream edge of the core spawning area and decrease at the upstream edge. To test the validity of the variable coefficient GAM we also used a geometric method that related the area and center of mass of the pollock spawning aggregation to spawning biomass, transport, and temperature in annual time steps. The area of the spawning aggregation was positively related to spawning biomass, but not to transport or temperature. Variable coefficient GAMs are a useful tool to disentangle the spatially explicit forces of density-dependent and density-independent processes on fish populations.

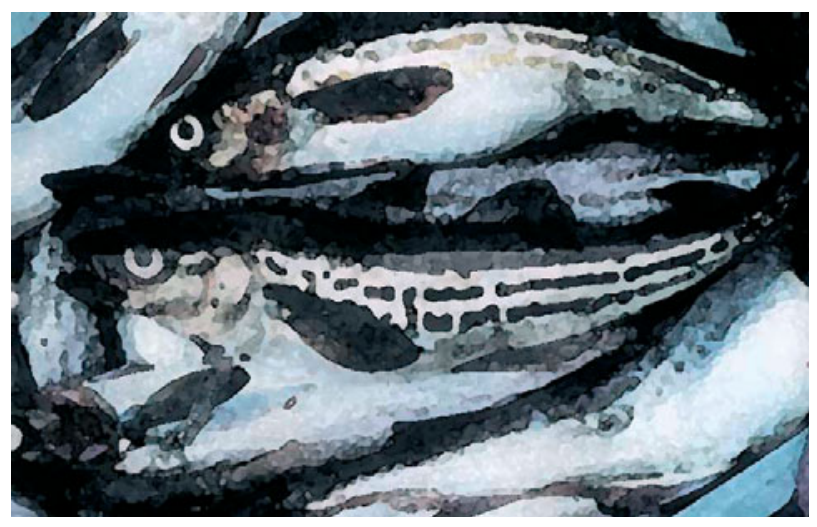

Commercially harvested walleye pollock Theragra chalcogramma in Alaska. Digitally altered photograph from Alaska Fisheries Science Center, NOAA

KEY WORDS: Reproduction - Spatial distribution . Generalized additive models · Gulf of Alaska · Density dependence $\cdot$ Recruitment

Resale or republication not permitted without written consent of the publisher

\section{INTRODUCTION}

Historically, models of fisheries population dynamics have focused on temporal instead of spatial variability of fish stocks, where demographic (population 
abundance) and environmental variables are averaged over large geographic areas and correlated among years (Myers 1998, Ciannelli et al. 2008). Although temporal studies have provided insight into the ways in which density-dependent and density-independent factors influence species dynamics (e.g. MacKenzie \& Köster 2004), they have the potential to misrepresent nonlinear species-environment interactions if average conditions are applied homogeneously over space (Ciannelli et al. 2007a). There is a widespread demand for population dynamics models that can explicitly account for spatial heterogeneity in the vital rates and distribution of organisms (Cadrin \& Secor 2009). Within the arena of spatial models, there are few examples that show the complex interactions of landscape, climate, and the density-dependent effects on spatial dynamics of marine fishes.

Spawning is an especially critical and sensitive period for marine fishes. Commercial fishing has historically targeted spawning aggregations of many commercial species (Sadovy \& Domeier 2005). In the case of walleye pollock Theragra chalcogramma (hereafter pollock), an intense fishery for valuable roe occurs just prior to spawning as the fish aggregate. The spatial and temporal dynamics of spawning set the stage for egg and larval growth and survival (Cushing 1990), and small changes in mortality rate during these early life-history stages can profoundly influence year-class strength (Houde 1987, Leggett \& DeBlois 1994). The timing and location of spawning can affect year-class variations through a variety of processes, such as egg and larval drift to favorable nursery areas (Iles \& Sinclair 1982). Harvesting spawning aggregations may impact spawning stock density and the age structure of the population, in turn affecting spawning time and location and egg abundance, which may subsequently influence larval survival. Therefore, understanding natural and human influences on spawning features, such as spatial variability, is important for resource management.

We used novel analytical techniques to model the spatial and temporal distribution of pollock eggs in the Gulf of Alaska as related to density-dependent and density-independent factors. Most of the pollock spawning in the Gulf of Alaska occurs within the Shelikof Strait (Kendall \& Picquelle 1990), a deep-sea valley between Kodiak Island and the Alaska Peninsula (Fig. 1). Shelikof Strait pollock is a model population to examine spawning spatial dynamics for several reasons. Pollock is one of the world's most heavily exploited fisheries, and the spawning aggregation of pollock in the Shelikof Strait has been tar-

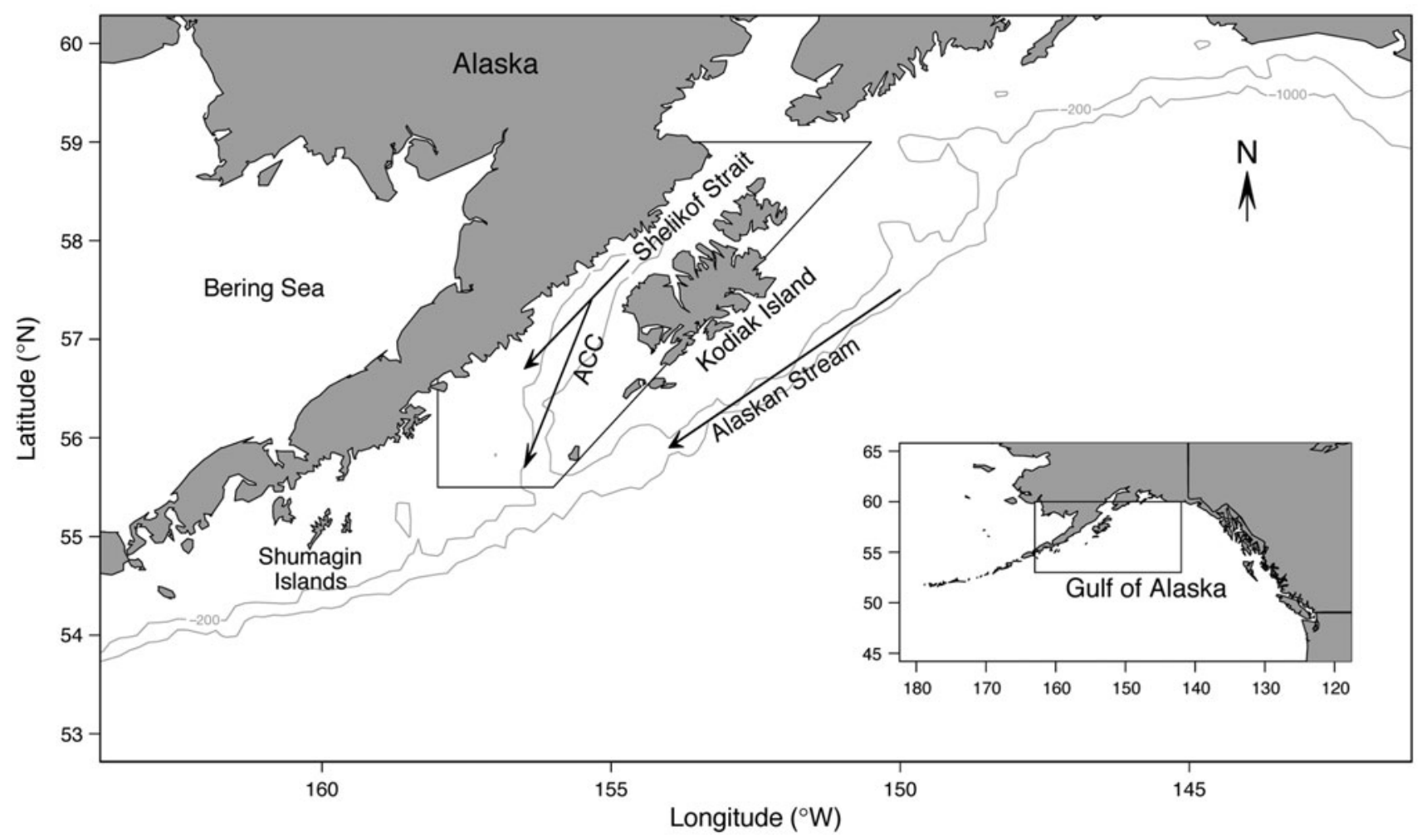

Fig. 1. Theragra chalcogramma. Shelikof Strait in the Gulf of Alaska, the primary walleye pollock spawning area in the region. Major ocean currents are shown by the arrows (ACC = Alaska Coastal Current). Bathymetry lines for 200 and $1000 \mathrm{~m}$ are also provided. Only samples occurring within the polygon were included in the analyses 
geted since the 1980s (Dorn et al. 2008). Pollock spawning in the Shelikof Strait is tractable to study because it is restricted in both space and time, historically occurring in a small part of the strait in early spring, from which a dense aggregation of eggs is produced (Kendall et al. 1987). Finally, pollock ichthyoplankton surveys have occurred in the Shelikof Strait since the 1970s (Kendall et al. 1996), a sufficient time to include at least one documented event of climate change (Hare \& Mantua 2000) and a dramatic rise and fall of the pollock population and harvest (Dorn et al. 2008). Pollock eggs are deep in the water column of Shelikof Strait, where horizontal transport is relatively weak (Kendall \& Picquelle 1990), and thus it is reasonable to infer spawning distribution from the egg distribution.

Ciannelli et al. (2007b) examined the geographical and phenological patterns of pollock eggs in the Gulf of Alaska as influenced by landscape and a regime shift effect. Our study departs from Ciannelli et al.'s (2007b) study in that we focus more explicitly on the well-defined spawning Shelikof aggregation, allowing us to magnify the effects of density (spawning biomass), climate variability, and fixed landscape effects on spawning location. We were interested in how density-dependent and density-independent factors affect spawning distribution. Therefore, we confined the analysis to an area that is likely to represent a unique (single) stock.

We used a novel spatially explicit variable coefficient generalized additive model (GAM; Hastie \& Tibshirani 1993, Wood 2006) that relates the spatial and temporal dynamics of pollock spawning aggregations to the potentially spatially heterogeneous effects of density-dependent and density-independent variables. Until very recently, these unique models have not been applied in an ecological setting (V. Bartolino et al. unpubl. data). We used these models to predict specific locations where pollock egg density was expected to increase or decrease with changes in spawning biomass, temperature, and ocean transport. We hypothesized that increased spawning biomass would increase pollock egg densities on the edge of the traditional spawning aggregation (i.e. spawning aggregation expansion), and increased transport would shift egg densities downstream in the Shelikof Strait due to egg drift (Kendall \& Picquelle 1990). To test the validity of the variable coefficient GAMs, we also related 2 geometric calculations of the pollock spawning aggregation to spawning biomass, transport, and temperature in annual time steps, testing the specific hypothesis that the spread of the spawning distribution is influenced by female biomass and environmental conditions.

\section{MATERIALS AND METHODS}

Egg collections. The locations and timing of pollock Theragra chalcogramma egg density were used to define spawning aggregations. Pollock egg density (number per $10 \mathrm{~m}^{2}$ ) data from the Gulf of Alaska were extracted from the Ichthyoplankton Cruise Database (see Matarese et al. 2003 for details), which consists of cruises conducted by the Alaska Fisheries Science Center (Seattle, Washington) since 1972. Bongo and Tucker trawls with 333 or $505 \mu \mathrm{m}$ mesh size were used to collect pollock eggs; different mesh sizes collected pollock eggs equally well because pollock eggs are relatively large $(>1.2 \mathrm{~mm}$ diameter) and possess a hard chorion that limits extrusion. Oblique tows generally were made from $10 \mathrm{~m}$ off the bottom to the surface in shelf areas or from a depth of $300 \mathrm{~m}$ to the surface in areas where water depth was $>300 \mathrm{~m}$. Nets equipped with a flowmeter were towed at a speed to maintain a $45^{\circ}$ wire angle at a retrieval rate of $20 \mathrm{~m} \mathrm{~min}^{-1}$. Eggs were preserved in $5 \%$ formalin and later sorted and identified to species at the Plankton Sorting and Identification Center in Szczecin, Poland.

To reduce sampling heterogeneity in space and time we restricted the samples included in our analyses. Years $(\mathrm{N}=28)$ were limited to those when sampling actually took place in the Gulf of Alaska during and immediately after the pollock spawning season (i.e. 1972, 1978 to 1979, 1981 to 2005). Only samples occurring within the Shelikof Strait and nearby areas in the Gulf of Alaska (see Fig. 1 for area selection) were utilized, because pollock spawning and ichthyoplankton sampling has been concentrated in this region (Ciannelli et al. 2007b). Only samples occurring from the 60 th to the 150th day of year (DOY; ca. 1 March to 30 May) and bottom depths from 33 to $403 \mathrm{~m}$ were included, so that the temporal and depth coverage among years was comparable. This temporal and depth range includes the bulk of pollock spawning activity in the Gulf of Alaska (Ciannelli et al. 2007b). Finally, only samples with non-zero pollock egg density were analyzed. Since we were primarily interested in describing centers of pollock egg density, the removal of zero egg tows in areas or times with consistently scarce eggs should not affect the results.

Variable coefficient GAM. A spatially explicit variable coefficient GAM (Hastie \& Tibshirani 1993, Wood 2006) was employed to test for variable spatial and temporal effects of covariates on pollock egg density in the Shelikof Strait. We examined the influence of 6 predictor variables (hereafter covariates) on egg density: spawning biomass, water temperature, transport, position, bottom depth, and DOY (Fig. 2). These particular covariates were chosen based on previous work in the Gulf of Alaska (e.g. Ciannelli et al. 2007b) and to address our specific hypotheses. 


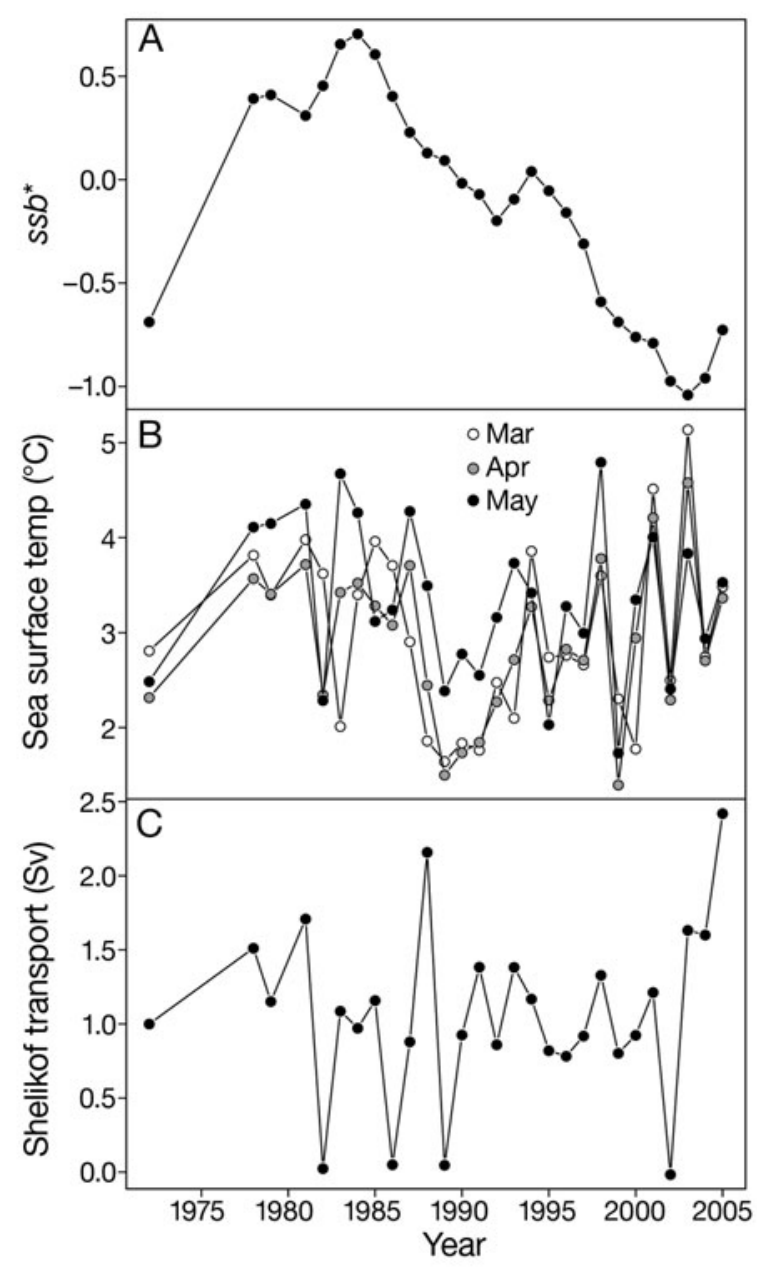

Fig. 2. Theragra chalcogramma. Time series of (A) walleye pollock standardized spawning biomass $\left(s s b^{\star}\right.$; natural logtransformed anomalies), (B) water temperature (monthly average), and (C) transport (average volume of water [Sverdrups, Sv] flowing through Shelikof Strait) used in the variable coefficient generalized additive model

Annual estimates of female spawning biomass were obtained from an age-structured assessment model for the Gulf of Alaska (Dorn et al. 2008). Since biomass estimates from the assessment are for the entire Gulf of Alaska, we estimated female spawning biomass for the Shelikof Strait by removing estimated female spawning biomass in the Shumagin Island region (Fig. 1; Dorn et al. 2008), which has been a secondary spawning area in the Gulf of Alaska (Ciannelli et al. 2007b). We assume, based on egg and larval surveys, that the Shumagin Islands region was a minor spawning area for pollock before 1989 (Matarese et al. 2003). The Shumagin spawning population was first noted during assessment surveys in 1989, increased to approximately $30 \%$ of the total Gulf of Alaska spawning biomass by 1993 (partly due to the decline of the Shelikof Strait population), and then declined to approximately
$10 \%$ by 2004 (Dorn et al. 2008). A smoothing function was assumed to fit changes in the Shumagin population, and the Shelikof Strait pollock spawning biomass was assumed to make up the remaining portion of Gulf of Alaska spawning biomass by difference. It was necessary to standardize spawning biomass $\left(s s b^{*}\right)$ as annual natural log anomalies because of the drastically different units of spawning biomass compared to other covariates.

Although previous work has shown that displacement of pollock eggs in Shelikof Strait due to ocean currents is minimal (Kendall \& Picquelle 1990), we included a transport variable (tr) in our GAM to account for variability in egg drift. Average daily transport, in Sverdrups units $\left(\mathrm{Sv} ; 10^{6} \mathrm{~m}^{3} \mathrm{~s}^{-1}\right)$ of water flowing through a plane across the Shelikof Strait, was estimated using a finite difference ocean circulation model (Hermann \& Stabeno 1996) developed specifically for the Shelikof Strait (M. Spillane, NOAA, Seattle, WA, unpubl. data). Average spring transport values were calculated as the average daily transport from the pollock spawning season (i.e. 1 March to 31 May).

Monthly water temperature $\left({ }^{\circ} \mathrm{C}\right)$ for the Shelikof Strait was taken from the National Centers for Environmental Prediction reanalysis derived data provided by the Physical Sciences Division of the National Oceanic and Atmospheric Administration (www.cdc.noaa.gov/, accessed 3 June 2009). Monthly sea surface temperature (temp) was used as a proxy for the water temperature experienced by pollock, because although pollock spawn at depth, bottom temperatures were not available for all years; this is a reasonable assumption because mean March to May sea surface temperature is strongly correlated with April bottom temperatures in Shelikof Strait for years with both measurements in common $\left(R^{2}=0.77\right.$; K. Bailey unpubl. data).

The spatially explicit variable coefficient GAM was formulated as:

$$
\begin{aligned}
x_{t, y,(\phi, \lambda)}= & a+\alpha_{1}(t e m p)+\alpha_{2}(t r)+\alpha_{3}\left(s s b_{Y}^{*}\right) \\
& +g_{1}(t)+g_{2}(\phi, \lambda)+g_{3}(d)+g_{4}(\phi, \lambda) \cdot s s b_{Y}^{*} \\
& +g_{5}(\phi, \lambda) \cdot \operatorname{temp}+g_{6}(\phi, \lambda) \cdot t r+e_{t, y,(\phi, \lambda)}
\end{aligned}
$$

where $x$ is pollock egg density, $a$ is the intercept, $e_{t, y,(\phi, \lambda)}$ is random error assumed to be normally distributed with zero mean and finite variance, the $\alpha$ s are linear functions, the $g$ s are nonparametric smoothing functions, $d$ is bottom depth in meters, $t$ is DOY, $\phi$ is latitude, and $\lambda$ is longitude. Due to model identifiability, all smoothed terms ( $g \mathrm{~s})$ were centered around 0 , and a constant (a) was added to the predictions to scale back to original values. However, the zero constraint does not necessarily hold for the spatially variable terms $g_{4-6}$ since an increase of, for instance, biomass may cause an increase of local egg abundance throughout 
the study region. To overcome this problem, we included globally linear terms for temp, tr and $s s b^{*}$. Hence, the effects of $g_{4-6}$ should be interpreted as variations around the overall linear effects $\alpha_{1}, \alpha_{2}$ and $\alpha_{3}$. For example, pollock egg density will increase, on average, by the amount $\alpha_{1}+g_{5}(\phi, \lambda)$ at site $(\phi, \lambda)$ per unit increase in temperature, given everything else being equal. The strength of the variable coefficient GAM approach is the ability to predict specific areas where pollock egg density is expected to increase or decrease given a 1-unit increase in a particular densitydependent $\left(s s b^{*}\right)$ or density-independent $(t r, t e m p)$ covariate.

The full formulation of Model 1 (Eq. 1) was compared to various reduced models using generalized cross validation (GCV; a measure of the out-of-sample predicted mean squared error), Akaike information criterion (AIC; Burnham \& Anderson 2002), and model diagnostics. We used the MGCV library (Wood 2004) in R (R Development Core Team 2008) to construct and compare all models. To test the robustness of the variable coefficient model, especially in regards to excluding zero catches (Pennington 1983, Stefánsson \& Pálsson 1997), we also constructed a binomial (presence/ absence) model that included the same linear and smoothed covariates, but used all data. Coefficients and fit of the binomial model were very similar to the variable coefficient model, so only the variable coefficient results are shown.

Geometric approach. An alternative approach related the area and centroid (i.e. geometric center of mass) of the pollock spawning aggregation each year to annual indices of female spawning biomass, transport, and temperature in the Shelikof Strait. Observed data alone were not used to calculate the area and centroid of pollock egg densities because these calculations were highly dependent upon slight annual inconsistencies in sampling in space and time, so instead we calculated the area and centroid from the predicted annual spatial distribution of eggs using a GAM. Pollock egg density data were log transformed to achieve normality and reduce heteroscedasticity. Covariates of the GAM included the DOY, the position of the sample in terms of latitude and longitude, and the year of the sample. Pollock egg density was predicted on a common day of the year (i.e. DOY 97, April 7) that corresponded with the peak pollock spawning in the Shelikof Strait (see 'Results'). The inclusion of the DOY and positional covariates in the GAM corrected for small inconsistencies in sampling over space and time that occurred among years. Eight additional years were excluded from this analysis (i.e. 1972, 1978 and 1979, 1999 and 2000, 2003 to 2005) given their insufficient spatial and temporal coverage within the central spawning area in the Shelikof Strait (Table 1).
In our GAM, we related the natural logarithm of pollock egg density, $x_{t, y_{1}(\phi, \lambda)}$, to the DOY $(t)$, year $(y)$, latitude $(\phi)$, and longitude $(\lambda)$ :

$$
x_{t, y,(\phi, \lambda)}=a+t e(\phi, \lambda, y)+g_{1}(t)+e_{t, y,(\phi, \lambda)}
$$

where $a$ is the intercept, $e_{t, y_{1}(\phi, \lambda)}$ is random error assumed to be normally distributed with zero mean and finite variance, $g_{1}$ is a nonparametric smoothing function, and te is a tensor product smoother of the 3-dimensional covariate of latitude, longitude, and year (Wood 2006). The tensor product is an appropriate smoother along the 3 axes in situations where product covariates have different unit scales and varying smoothness (Wood 2004). The tensor product was used because it allowed for a different 2-dimensional spatial pattern of pollock egg density each year of the study. The tensor product GAM was suitable because the spawning distribution of pollock was fairly consistent among years, yet separate yearly models could not be fit because of inconsistencies in sampling in space and time. Several reduced models were tested using GCV

Table 1. Theragra chalcogramma. The years studied with each model, the number of non-zero samples $(\mathrm{N})$, and the start and end dates for collection of the walleye pollock egg data set in the Shelikof Strait, Gulf of Alaska. VC GAM: variable coefficient generalized additive model only; BOTH: geometric model and VC GAM

\begin{tabular}{|c|c|c|c|c|}
\hline Year & $\mathrm{N}$ & Start date & End date & Model \\
\hline 1972 & 9 & 29 Apr & 9 May & VC GAM \\
\hline 1978 & 6 & 31 Mar & $12 \mathrm{Apr}$ & VC GAM \\
\hline 1979 & 6 & 7 Mar & 20 May & VC GAM \\
\hline 1981 & 293 & $12 \mathrm{Mar}$ & $28 \mathrm{May}$ & ВОТН \\
\hline 1982 & 39 & 7 Apr & 27 May & BOTH \\
\hline 1983 & 16 & 21 May & 25 May & BOTH \\
\hline 1984 & 88 & 4 Apr & 1 May & ВОTH \\
\hline 1985 & 291 & 17 Mar & 28 May & ВOTH \\
\hline 1986 & 190 & $5 \mathrm{Apr}$ & 18 May & BOTH \\
\hline 1987 & 141 & 4 Apr & $22 \mathrm{Apr}$ & BOTH \\
\hline 1988 & 236 & 25 Mar & $12 \mathrm{Apr}$ & ВОTH \\
\hline 1989 & 302 & 6 Apr & 16 May & BOTH \\
\hline 1990 & 185 & $8 \mathrm{Apr}$ & 30 May & BOTH \\
\hline 1991 & 282 & 2 Apr & 25 May & BOTH \\
\hline 1992 & 210 & $6 \mathrm{Apr}$ & 28 May & BOTH \\
\hline 1993 & 192 & $6 \mathrm{Apr}$ & 30 May & BOTH \\
\hline 1994 & 150 & 16 Mar & 30 May & ВOTH \\
\hline 1995 & 38 & 24 May & 28 May & BOTH \\
\hline 1996 & 197 & $28 \mathrm{Apr}$ & 30 May & ВОTH \\
\hline 1997 & 35 & 24 May & 30 May & ВOTH \\
\hline 1998 & 99 & 3 May & 28 May & ВОТН \\
\hline 1999 & 18 & 26 May & 30 May & VC GAM \\
\hline 2000 & 6 & 29 May & 30 May & VC GAM \\
\hline 2001 & 101 & 29 Apr & 30 May & ВOTH \\
\hline 2002 & 33 & 27 May & 30 May & ВОТН \\
\hline 2003 & 7 & $30 \mathrm{Apr}$ & 30 May & VC GAM \\
\hline 2004 & 26 & 27 May & 30 May & VC GAM \\
\hline 2005 & 23 & 26 May & 30 May & VC GAM \\
\hline
\end{tabular}


and AIC that excluded a number of covariates. Based on GCV and AIC scores and model diagnostics using the 'gam.check' function, the full model (Eq. 2) outperformed all reduced models, so only the full model is presented.

Next, we used Model 2 (Eq. 2) to predict the unique spatial pattern of pollock egg density for each year of study. A grid of cells measuring $5 \mathrm{~km} \times 5 \mathrm{~km}$ was created over our study area, within which predicted pollock egg densities were estimated. All grid points with bottom depths $>0$ (i.e. land) were excluded so as to not bias geometric calculations. We selected only those grid points for which local predictions were greater than the 80th percentile of the overall predicted egg densities. Hereafter, we refer to these grid points as 'core egg density areas'. Increasing or decreasing the percentile used to predict core egg density areas had no material affect on the regression analyses below.

We then related the annual area and centroid of pollock core egg density areas to spawning biomass (original scale, in metric tons), transport, and temperature. The area $\left(\mathrm{km}^{2}\right)$ and centroid (latitude, longitude) of each annual core egg density area were estimated using the 'PBSmapping' library in R. The spatial coordinates of the centroid were converted to a linear distance $(\mathrm{km})$ along the Shelikof Strait axis, with a zero value given to the most northeastern point and positive values assigned to those points located in the southwestern direction. Linear models were used to relate response variables (area and distance along axis) to spawning biomass, transport, and temperature. Each year $(N=20)$ was considered an independent replicate for these analyses.

\section{RESULTS}

After removing samples that failed to catch pollock Theragra chalcogramma eggs $(\mathrm{N}=1166$ samples; $26.6 \%$ of total), pollock egg density ranged from 3 to 635692 eggs per $10 \mathrm{~m}^{2}$. The highest pollock egg density occurred in the Shelikof Strait and downstream regions, and decreased markedly elsewhere (Fig. 3).

\section{Variable coefficient GAM}

Overall, $28 \mathrm{yr}$ of data were included in the variable coefficient GAM, encompassing 3219 samples with positive pollock egg catches, with an average of 115 samples per year (Table 1). The GAM that included all parametric, smoothed, and variable coefficient terms, except the parametric term for spawning biomass, slightly outperformed the full and substantially outperformed all other reduced models based on GCV and AIC scores (Table 2). This model explained $83 \%$ of the deviance in observed pollock egg density and was the only model subsequently considered.

At average values of all other covariates, the effect of spatial position on pollock egg density was highest in the Shelikof Strait, and decreased outside of the Shelikof Strait (Fig. 4A). The timing of egg density peaked between DOY 90 and 110 (corresponding to 30 March-19 April), with a minor peak around DOY 140 (19 May; Fig. 4B). Pollock egg densities were highest in water depths $>250 \mathrm{~m}$ (Fig. 4C).

Both parametric terms (temperature and transport) included in the GAM had a negative effect on pollock egg density in the Shelikof Strait (Table 2). Moreover,

Table 2. Theragra chalcogramma. Model selection for the spatially explicit variable coefficient generalized additive model for walleye pollock egg density. Estimated coefficients are shown for parametric terms, and estimated degrees of freedom are shown for nonparametric terms. Asterisks denote significance at the following alpha levels: ${ }^{*} 0.05 ;{ }^{* *} 0.01 ;{ }^{* * *} 0.001$; na: covariate was not applicable to that particular model; GCV: generalized cross validation score; AIC: Akaike information criterion; Dev. ex.: deviance explained by the model. Base is: $x_{t, y,(\phi, \lambda)}=a+\alpha_{1}(t e m p)$ $+\alpha_{2}(t r)+\alpha_{3}\left(s s b_{y}^{*}\right)+g_{1}(t)+g_{2}(\phi, \lambda)+g_{3}(d)+g_{4}(\phi, \lambda) \cdot s s b_{y}^{*}+g_{5}(\phi, \lambda) \cdot t e m p+g_{6}(\phi, \lambda) \cdot t r+e_{t, y,(\phi, \lambda)}$, where $x$ is log-transformed walleye pollock egg density, $a$ is the intercept, $\alpha$ s are linear functions, temp is water temperature, $t r$ is the transport index, $g$ s are nonparametric smoothing functions, ss $b^{*}$ is standardized spawning biomass, $t$ is the day of the year, $d$ is log-transformed bottom depth, $\phi$ is latitude, $\lambda$ is longitude, $y$ is the year, and $e_{t, y,(\phi, \lambda)}$ is the random error

\begin{tabular}{|c|c|c|c|c|c|c|c|c|c|c|c|c|c|}
\hline Model & $a$ & $\alpha_{1}(t e m p)$ & $\alpha_{2}(t r)$ & $\alpha_{3}\left(s s b_{y}^{*}\right)$ & $g_{1}(t)$ & $g_{2}(\phi, \lambda)$ & $g_{3}(d)$ & $g_{4}(\phi, \lambda) \cdot s s b_{y}^{*}$ & $g_{5}(\phi, \lambda) \cdot$ temp & $g_{6}(\phi, \lambda) \cdot \operatorname{tr}$ & GCV & AIC & Dev. ex. $(\%)$ \\
\hline Base $-\alpha_{3}\left(s s b_{y}^{*}\right)$ & $6.9^{* * *}$ & $-0.2^{* * *}$ & $-0.2^{* * *}$ & na & $8.9^{* * *}$ & $25.0^{* * *}$ & $5.4^{* * *}$ & $21.5^{* * *}$ & $8.4^{*}$ & $24.8^{* * *}$ & 1.553 & 10551.9 & 83.0 \\
\hline Base & $6.9^{* * *}$ & $-0.2^{* * *}$ & $-0.2^{* * *}$ & 0.1 & $8.9^{* * *}$ & $25.1^{* * *}$ & $5.4^{* * *}$ & $21.3^{* * *}$ & $8.6^{*}$ & $24.8^{* * *}$ & 1.554 & 10552.0 & 83.0 \\
\hline Base $-g_{5}(\phi, \lambda) \cdot$ temp & $6.9^{* * *}$ & $-0.2^{* * *}$ & $-0.3^{* * *}$ & 0.1 & $8.9^{* * *}$ & $25.5^{* * *}$ & $5.4^{* * *}$ & $21.4^{* * *}$ & na & $25.0^{* * *}$ & 1.557 & 10559.1 & 82.9 \\
\hline Base $-\alpha_{1}(t e m p)$ & $6.4^{* * *}$ & na & $-0.2^{* * *}$ & 0.0 & $8.9^{* * *}$ & $25.0^{* * *}$ & $5.5^{* * *}$ & $21.6^{* * *}$ & $9.4^{*}$ & $25.0^{* * *}$ & 1.569 & 10583.2 & 82.8 \\
\hline Base $-\alpha_{2}(\operatorname{tr})$ & $6.7^{* * *}$ & $-0.2^{* * *}$ & na & $0.2^{* *}$ & $8.9^{* * *}$ & $23.7^{* * *}$ & $5.3^{* * *}$ & $21.4^{* * *}$ & $10.3^{*}$ & $24.2^{* * *}$ & 1.575 & 10596.8 & 82.7 \\
\hline Base $-g_{6}(\phi, \lambda) \cdot t r$ & $7.0^{* * *}$ & $-0.2^{* * *}$ & $-0.2^{* * *}$ & 0.1 & $8.8^{* * *}$ & $18.9^{* * *}$ & $5.5^{* * *}$ & $20.2^{* * *}$ & $15.9^{* * *}$ & na & 1.584 & 10615.8 & 82.4 \\
\hline Base $-g_{4}(\phi, \lambda) \cdot s s b_{Y}^{*}$ & $7.0^{* * *}$ & $-0.2^{* * *}$ & $-0.3^{* * *}$ & 0.1 & $8.6^{* * *}$ & $23.2^{* * *}$ & $5.7^{* * *}$ & na & $15.4^{* * *}$ & $20.2^{* * *}$ & 1.633 & 10713.2 & 81.9 \\
\hline Base $-g_{3}(d)$ & $7.0^{* * *}$ & $-0.2^{* * *}$ & $-0.3^{* * *}$ & 0.1 & $8.9^{* * *}$ & $23.9^{* * *}$ & na & $22.8^{* * *}$ & $14.9^{* * *}$ & $25.4^{* * *}$ & 1.712 & 10864.4 & 81.3 \\
\hline Base $-g_{1}(t)$ & $7.3^{* * *}$ & $-0.5^{* * *}$ & $0.1^{* *}$ & 1.4 & na & $20.8^{* * *}$ & $2.0^{* * *}$ & $19.8^{* * *}$ & $10.0^{* *}$ & $13.6^{* * *}$ & 3.408 & 13082.5 & 62.0 \\
\hline
\end{tabular}




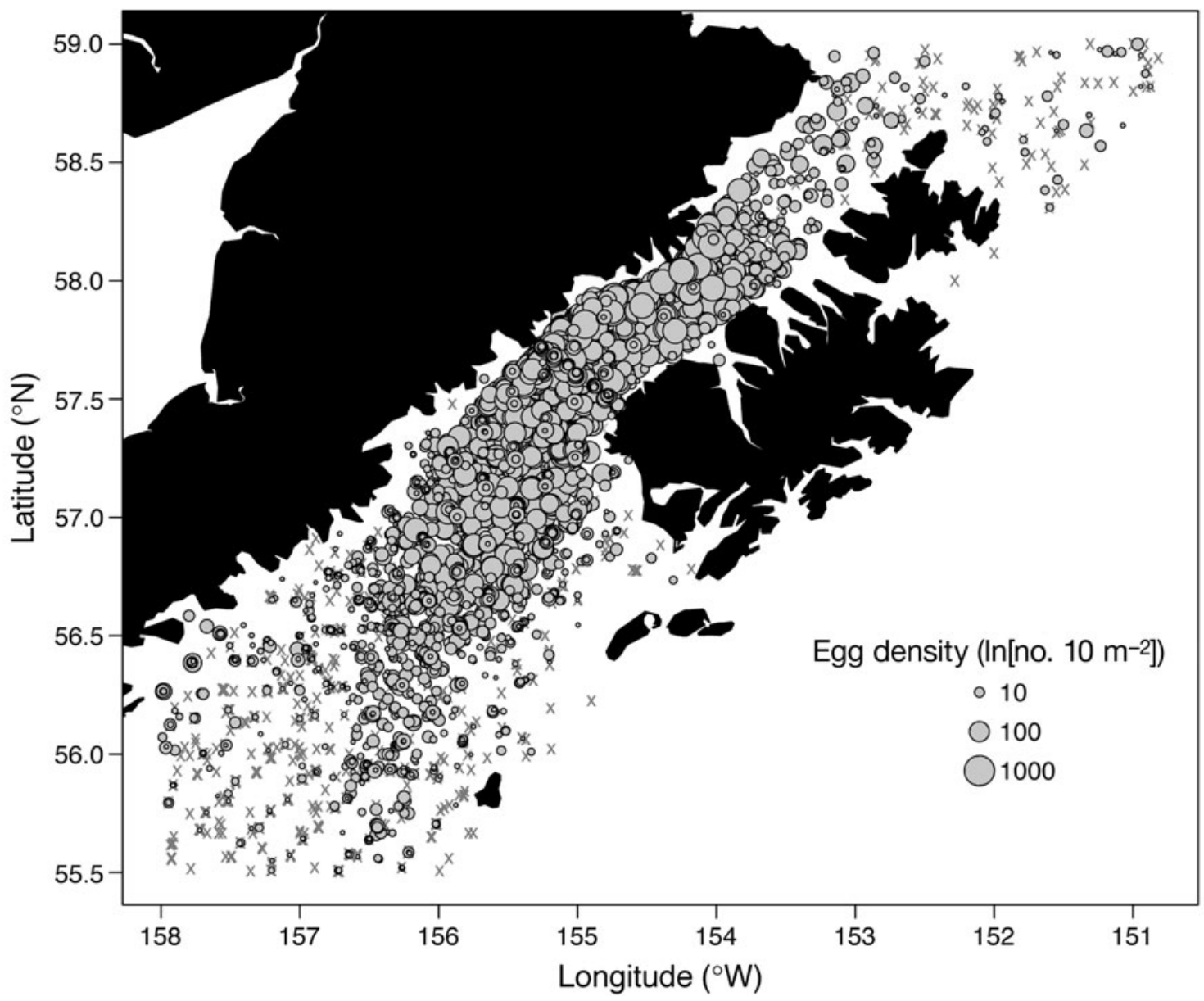

Fig. 3. Theragra chalcogramma. Log-transformed walleye pollock egg densities (number per $10 \mathrm{~m}^{2}$ ) collected over the $28 \mathrm{yr}$ of the study in the Shelikof Strait region of the Gulf of Alaska. x: sample for which no walleye pollock eggs were caught and therefore excluded from analyses

we observed spatially explicit effects of spawning biomass, temperature, and transport on pollock egg density as measured by the variable coefficient terms of the GAM (Fig. 5). Specifically, an increase in spawning biomass had a positive effect on egg density at the periphery of the core egg density area, suggesting an expansion of spawning area at high spawning biomass levels and a contraction at low levels (Fig. 5A). The negative effect of spawning biomass on egg densities at the southern edge of the study area was somewhat trivial because baseline egg densities here were initially very low.

Temperature had a weak spatial effect, with slight increases in pollock egg density around the northern edge of Kodiak Island with increased temperature, and slight concomitant decreases in pollock egg density in a small area southwest of Shelikof Strait with increased temperature (Fig. 5B). Increases in transport through the Shelikof Strait caused pollock egg density to increase at the downstream (southwest) edge of the pollock core egg density area and decrease at the upstream (northeast) edge (Fig. 5C). Increased spawning biomass and transport also resulted in an increase of egg density in the far northeastern corner of our study area, likely a result of eggs spilling over from an upstream spawning population (e.g. Amatuli Trough, Prince William Sound, or Resurrection Bay).

\section{Geometric approach}

For the 20 yr of data included in the geometric analyses, 3118 samples were analyzed that had positive pollock egg catches, with an average of 156 samples $\mathrm{yr}^{-1}$. The 80th percentile of pollock egg densities predicted from the tensor product GAM was 4915 eggs per $10 \mathrm{~m}^{2}$; areas with higher predicted egg density than this value were considered core egg density areas. The area occupied by core egg density areas ranged from a minimum of $4178 \mathrm{~km}^{2}$ in 1998 to a maximum of 
$8913 \mathrm{~km}^{2}$ in 1988 (Fig. 6), the 2 yr with low and high spawning biomass, respectively. The centroid of pollock core egg density areas was found farthest to the northeast in 1995 and farthest to the southwest (76.1 km away) in 2002 (Fig. 6).
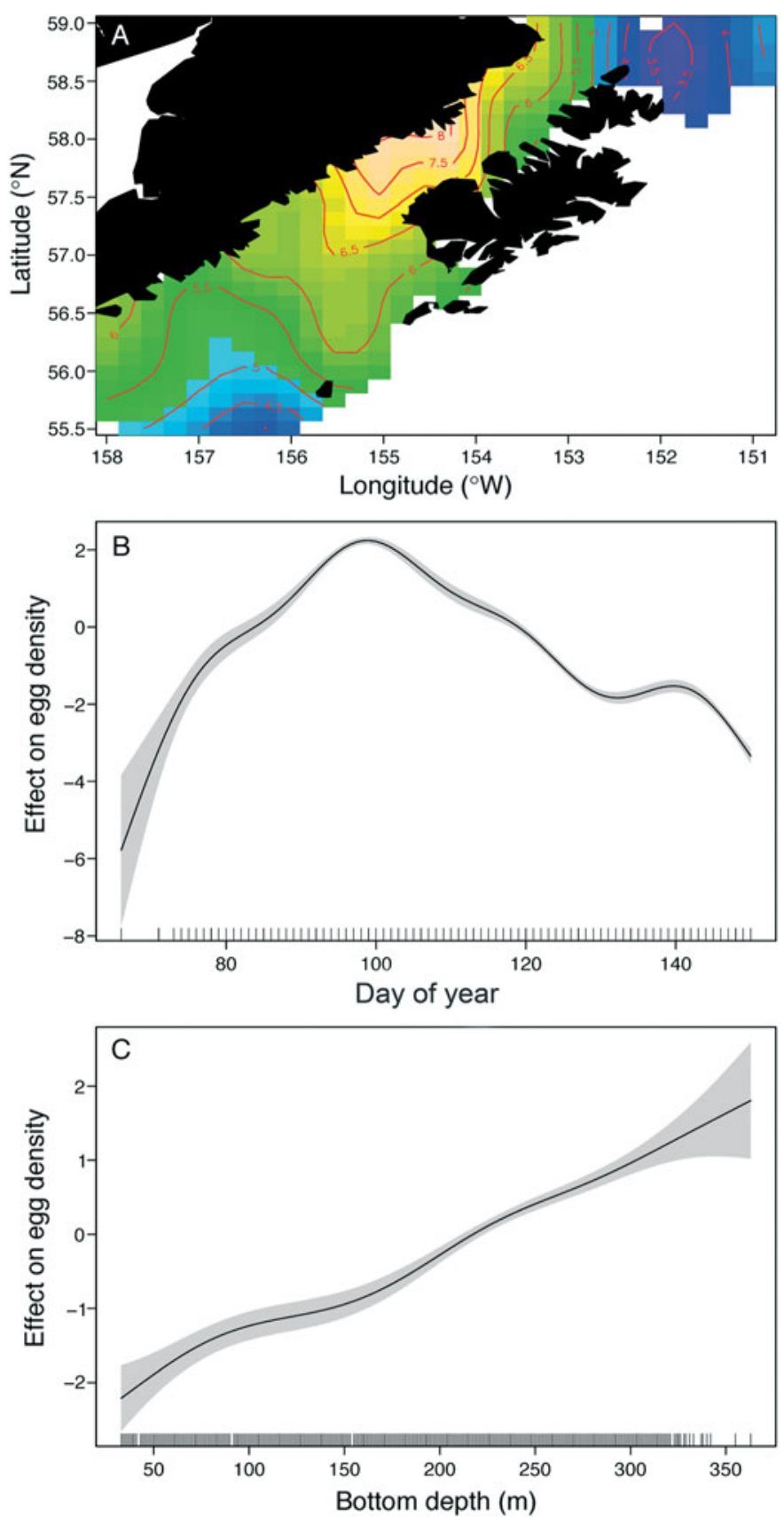

Fig. 4. Theragra chalcogramma. Partial effects of (A) position, (B) day of the year (DOY), and (C) bottom depth on walleye pollock egg density, estimated from the spatially explicit variable coefficient generalized additive model. For the position plot, orange indicates high predicted density and blue indicates low density. Shaded areas on DOY and bottom depth plots are $95 \%$ confidence intervals, and tick marks on the $X$-axis indicate sampling intensity
The geometric area of pollock core egg density was positively related to Shelikof Strait spawning biomass ( $p=0.04$; Fig. 7), but not to transport or temperature $(p>0.05)$. The distance along the Shelikof Strait axis of the centroid of egg density areas was not related to the annual index of Shelikof Strait transport, spawning biomass, or temperature $(\mathrm{p}>0.05)$.

\section{DISCUSSION}

Density-dependent, landscape, and temperature variability affects the spatial and temporal dynamics of animal distribution and abundance, but rarely are these variables considered simultaneously. We developed a novel application of a spatially explicit GAM approach, and used it to understand both the timing and distribution of spawning of an economically and ecologically important subarctic fish. This model allowed us to document various ways in which a mosaic of density-dependent, landscape, and environmental effects combined to shape the spatio-temporal distribution of pollock Theragra chalcogramma spawning aggregations in Shelikof Strait. Most importantly, we showed how the response of pollock egg density to spawning biomass, temperature, and transport has a spatial structure, the presence of which has a number of ecological and fisheries implications detailed below.

Spatially explicit variable coefficient GAMs can help to elucidate a variety of important ecological processes. From an ecological perspective, the main advantage of GAMs over other approaches like areal distribution indices and central tendency measures (Petitgas 1998) is the potential to quantify the simultaneous effects of density-dependent and densityindependent processes on the spatial and temporal distributions of a species of interest. Variable coefficient models are ideally suited to situations where the distribution of a species, as well as that of any potential covariates, is measured over space and throughout time (Hastie \& Tibshirani 1993). In a fisheries context, variable coefficient models can help identify those habitats of fish species that are considered essential for the reproduction, survival, and growth (Beck et al. 2001). By defining essential fish habitats over space, these models may also be particularly useful in the design of marine protected areas (Botsford et al. 2009).

Most studies of density dependence have examined either temporal processes such as mortality or spatial processes such as crowding, but relatively few have linked temporal changes in population abundance to spatial processes. Several studies have documented changes in geographic distribution with population abundance (e.g. Swain \& Wade 1993), but rarely have changes in the geographical distribution of spawning 


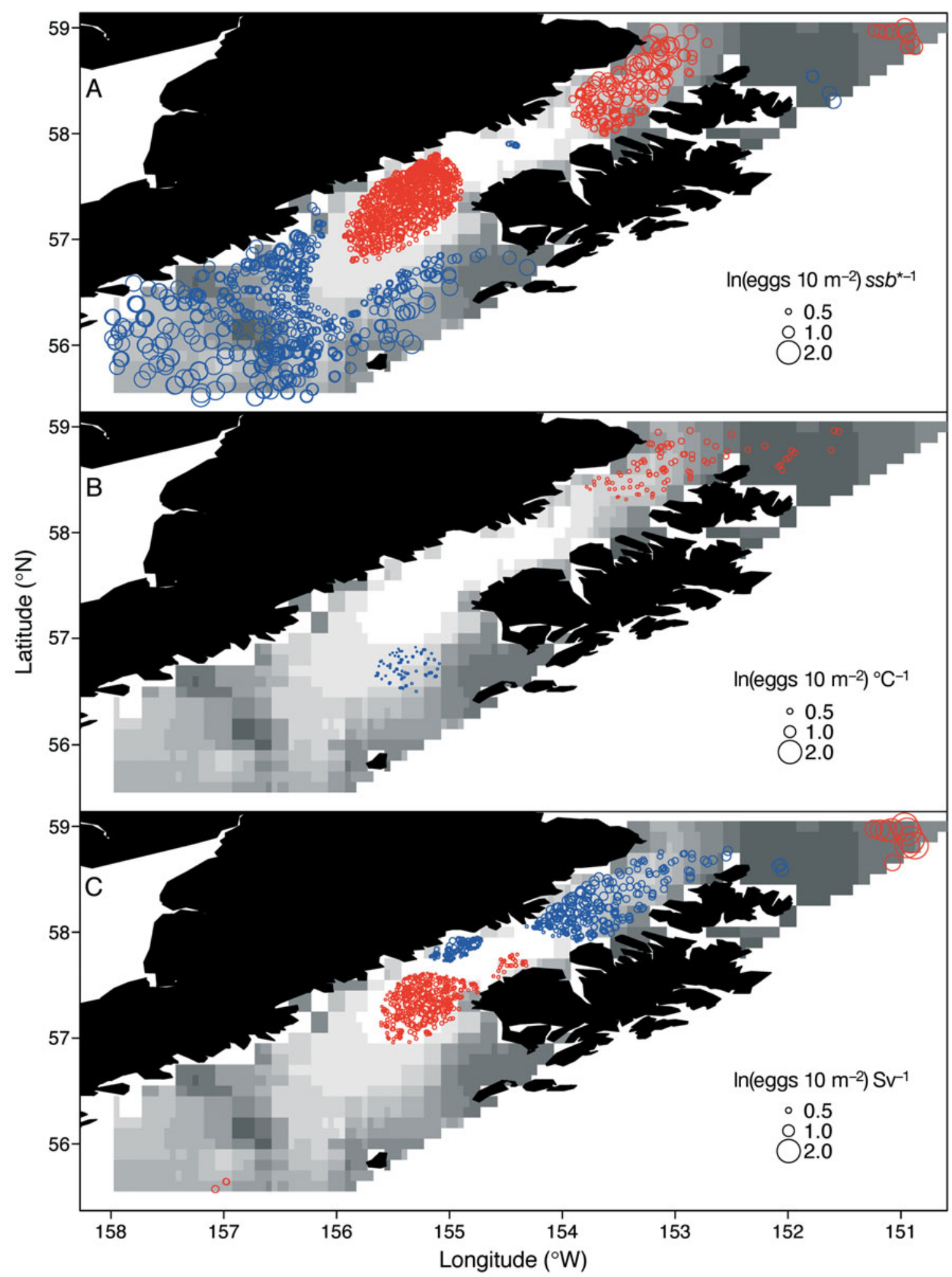

Fig. 5. Theragra chalcogramma. Spatially explicit variable coefficient generalized additive model plots for the effects of (A) walleye pollock standardized spawning biomass $\left(s s b^{*}\right)$, (B) sea surface temperature, and (C) transport (in Sverdrups, Sv) on walleye pollock egg density (number per $10^{2}$, log transformed). Light gray grid cells denote highest overall predicted egg densities and dark gray cells denote the lowest. Overlaid on grid cells are red or blue bubbles, which indicate an expected increase or decrease, respectively, in log-transformed egg density with a 1-unit increase in the covariate. Size of the bubbles is scaled to the size of the positive or negative effect; effects not significantly different from zero are excluded 


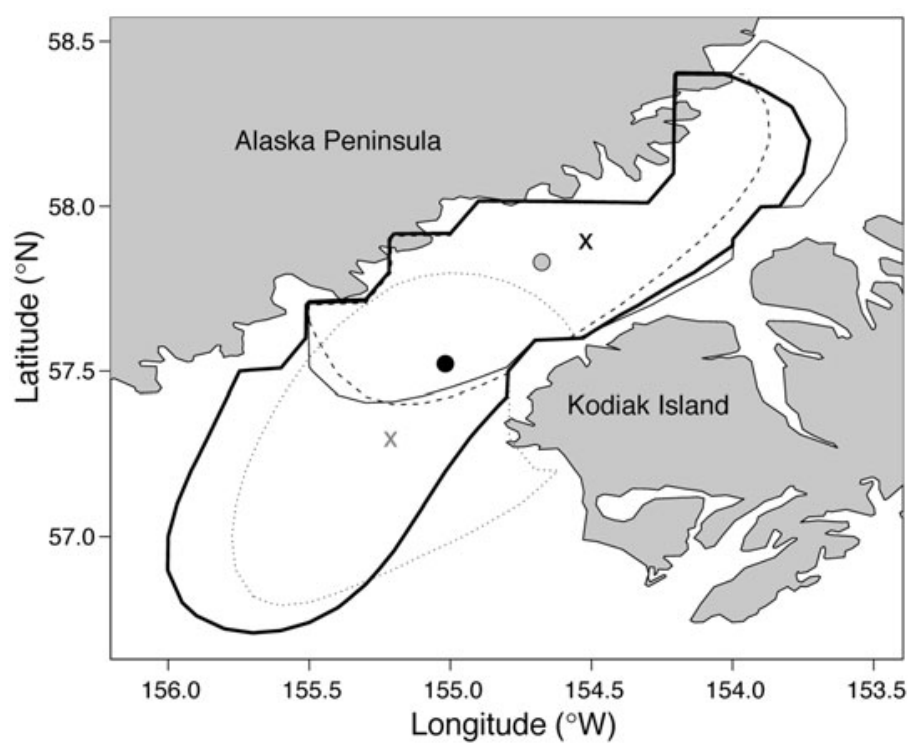

Fig. 6. Theragra chalcogramma. Contour lines and centroids derived from the geometric approach for walleye pollock core egg density areas in the Shelikof Strait, Gulf of Alaska. Contour lines of core egg density areas (i.e. 80th percentile of predictions) and centroids are shown for the following 4 years specifically mentioned in the text: $1988=$ thick solid line and black point; $1995=$ thin solid line and black ' $X$ '; $1998=$ dashed line and gray point; $2002=$ dotted line and gray ' $x$ '

been linked to population density (but see Watanabe et al. 1997). Others have linked spawning distribution to environmental factors (Eastwood et al. 2001, Bellier et al. 2007), but studies linking both environmental factors and spawning biomass to geographical distribution of spawning and eggs are novel. Using 2 independent approaches, we determined that the recent decline of pollock spawning biomass in Shelikof Strait

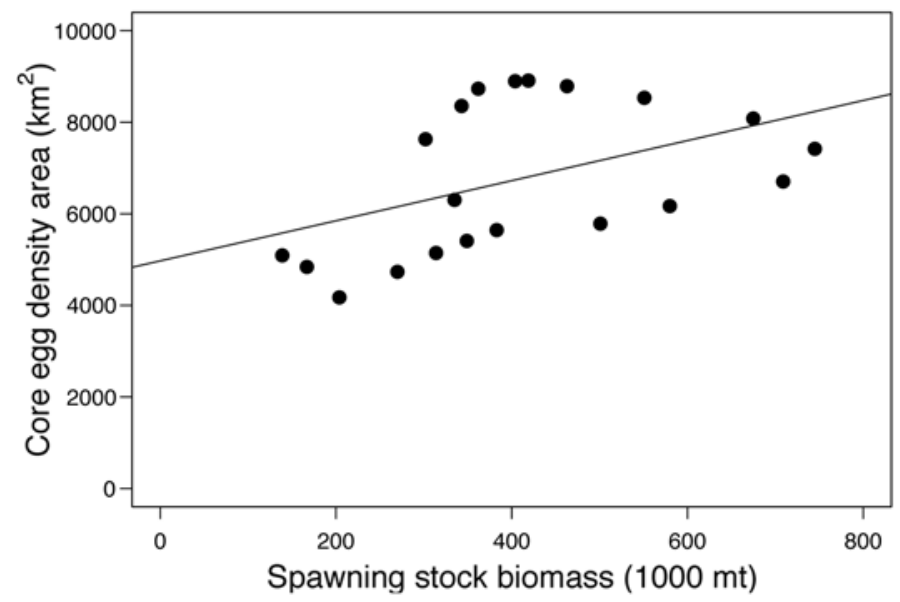

Fig. 7. Theragra chalcogramma. Scatter plot relating the size of the walleye pollock core egg density areas to spawning biomass in the Shelikof Strait, Gulf of Alaska, for $20 \mathrm{yr}$ of survey data. Trend line indicates least squares fit from a linear model has resulted in a contraction of the spawning area. It is clear that both density-dependent and densityindependent processes must be understood in combination to fully grasp the complexities of the spatial patterns of fish distribution (Fromentin et al. 2001, Shepherd \& Litvak 2004).

Although decreasing pollock spawning biomass resulted in a contraction of the spatial distribution of eggs, we did not observe an overall decrease in egg density with reductions in spawning biomass (determined by the exclusion of the parametric term for spawning biomass in our variable coefficient GAM). Three primary models have been developed to describe the ways in which the local response of density changes with a global change in abundance (reviewed by Petitgas 1998). The constant density model suggests that density remains constant, but the area covered by the stock varies with abundance (Iles \& Sinclair 1982). The proportional model proposes that the occupied area stays constant and local density varies proportionally to abundance (Myers \& Stokes 1989), whereas the basin model suggests both density and area vary with abundance (MacCall 1990). From our analyses, it appears that pollock spawning in Shelikof Strait is consistent with the constant density model, because the area of the spawning aggregation has expanded and contracted in relation to the global abundance of spawners. It is not known which spawning behaviors lead to expansion or contraction of spawning area while the density of spawners remains unchanged, but social interactions such as male territoriality during the spawning period, which has been documented for pollock in the laboratory (Baird \& Olla 1991, Park et al. 1994), is one potential mechanism.

Many processes operating at different temporal and spatial scales affect the recruitment of marine fishes (Stenseth et al. 1999). In the case of pollock, year-class abundance was initially thought to be due to the environmental conditions experienced by eggs and larvae (Megrey et al. 1996, Hamatsu et al. 2004). Recent evidence suggests that environmental conditions can also mediate the influence of density-dependent processes occurring between the pollock egg and juvenile stages, and predators and water temperature can continue to modify abundance well into the juvenile stage (Bailey 2000, Ciannelli et al. 2004, Bailey et al. 2005). Smaller spawning aggregations and subsequent patches of eggs can be expected to be more dependent on conditions in a narrower habitat. The recent decline of pollock spawning biomass in the Shelikof Strait has resulted in shrinkage of the spawning aggregation and may thus adversely influence recruitment, having a negative feedback effect on the population.

Ocean currents in Shelikof Strait, as measured by the transport index, added an important level of real- 
ism to our analyses. We included transport in our model to account for the potential drift of eggs between spawning and egg collection. Whereas the spatial effects of transport on egg density were not surprising (i.e. higher egg density in downstream locations during high transport), the negative effect of transport on overall pollock egg density was unexpected. The most likely explanation is that periods of high transport pushed eggs out of our sampling area, resulting in fewer eggs collected. However, the predicted centroid of pollock egg patches varied by only $76 \mathrm{~km}$ across the different transport extremes, suggesting transport effects, although significant, were not very strong. The second possibility is that higher transport levels directly reduced egg density due to a direct effect on spawning in the area.

A necessary by-product of the tensor product GAM was that the calculations of the area and centroid of pollock eggs among years were smoothed (Wood 2006), resulting in temporally autocorrelated geometric calculations. As a consequence, the assumption of independence of the linear model relating the area of spawning to spawning biomass was likely violated. However, the observed positive relationship was informative and fully supported by the variable coefficient GAM results, the latter of which is a more reliable method for determining the effects of spawning biomass on the spatial distribution of spawning. Another issue in the geometric approach was the way the annual centroid of pollock eggs was compared to Shelikof Strait transport. By necessity, a Shelikof Strait transport index of averaged values from March to May each year was used, but, since transport exhibits substantial variability over time scales of days to weeks (Hermann \& Stabeno 1996), this average index may not have reflected the true drift experienced by individual pollock eggs over their time in the water column. This is one explanation for the lack of an observed relationship between transport and the centroid of pollock egg mass, and is another strength of the variable coefficient GAM over the geometric approach.

There is ample evidence of the ways in which eggs and larvae are affected by climate variability (e.g. Ciannelli et al. 2005, Duffy-Anderson et al. 2005, Hsieh et al. 2009), especially temperature. Temperature has been shown to strongly influence recruitment of marine fish, particularly those at the northern or southern limits of their distributional ranges (Myers 1998, MacKenzie \& Köster 2004). We showed that increasing temperature slightly reduces pollock egg density in Shelikof Strait, although the magnitude of the effect seems relatively minor compared to standardized spawning biomass and transport effects. The exact mechanisms of how temperature influences pollock egg abundance or survival have not been elucidated, but we suggest they are related to egg turnover by temperature effects on hatching rate, or perhaps an effect on the dispersal of spawning. The latter effect is somewhat supported by enhanced spawning at the north end of the survey grid with warming conditions (Fig. 5B).

We combined simple geometric calculations with a powerful spatially explicit variable coefficient GAM to determine the relative influence of a suite of densitydependent and density-independent variables on the abundance and distribution of pollock eggs in Shelikof Strait. Our results suggest that future studies of population dynamics should not only consider variables that directly influence the abundance of eggs, but also how those variables affect the spatial distribution of eggs. Better knowledge of both the temporal and spatial dynamics of egg and larval distributions will improve our understanding of fluctuations in marine fish populations.

Acknowledgements. This research was supported by the Essential Fish Habitat program of the Alaska Regional Office and Alaska Fisheries Science Center, as well as the BSIERP program of the North Pacific Research Board (NPRB). This paper is Contribution EcoFOCI-723 to NOAA's Ecosystems and Fisheries-Oceanography Coordinated Investigations, BEST-BSIERP Publication No. 3, and NPRB Publication No. 220. We appreciate comments by J. Duffy-Anderson, Jeff Napp, T. Smart, and I. Speis. A. Dougherty compiled some of the environmental data.

\section{LITERATURE CITED}

Bailey KM (2000) Shifting control of recruitment of walleye pollock Theragra chalcogramma after a major climactic ecosystem change. Mar Ecol Prog Ser 198:215-224

Bailey KM, Ciannelli L, Bond NA, Belgrano A, Stenseth NC (2005) Recruitment of walleye pollock in a physically and biologically complex ecosystem: a new perspective. Prog Oceanogr 67:24-42

Baird TA, Olla BL (1991) Social and reproductive behavior of a captive group of walleye pollock Theragra chalcogramma. Environ Biol Fishes 30:295-301

Beck MW, Heck KL, Able KW, Childers DL and others (2001) The identification, conservation, and management of estuarine and marine nurseries for fish and invertebrates. Bioscience 51:633-641

> Bellier E, Planque B, Petitgas P (2007) Historical fluctuations in spawning location of anchovy (Engraulis encrasicolus) and sardine (Sardina pilchardus) in the Bay of Biscay during 1967-73 and 2000-2004. Fish Oceanogr 16:1-15

> Botsford LW, Brumbaugh DR, Grimes C, Kellner JB and others (2009) Connectivity, sustainability, and yield: bridging the gap between conventional fisheries management and marine protected areas. Rev Fish Biol Fish 19:69-95

Burnham KP, Anderson DR (2002) Model selection and multimodal inference: a practical information-theoretic approach, 2nd edn. Springer, New York

Cadrin SX, Secor DH (2009) Accounting for spatial population structure in stock assessment: past, present, and future. In: Beamish RJ, Rothschild BJ (eds) The future of fisheries sci- 
ence in North America. Springer, New York, p 405-426

Ciannelli L, Chan KS, Bailey KM, Stenseth NC (2004) Nonadditive effects of the environment on the survival of a large marine fish population. Ecology 85:3418-3427

Ciannelli L, Bailey KM, Chan KS, Belgrano A, Stenseth NC (2005) Climate change causing phase transitions of walleye pollock (Theragra chalcogramma) recruitment dynamics. Proc R Soc Lond B Biol Sci 272:1735-1743

> Ciannelli L, Dingsør GE, Bogstad B, Ottersen F and others (2007a) Spatial anatomy of species survival: effects of predation and climate-driven environmental variability. Ecology 88:635-646

Ciannelli L, Bailey KM, Chan KS, Stenseth NC (2007b) Phenological and geographical patterns of walleye pollock (Theragra chalcogramma) spawning in the western Gulf of Alaska. Can J Fish Aquat Sci 64:713-722

Ciannelli L, Fauchald P, Chan KS, Agostini VN, Dingsør GE (2008) Spatial fisheries ecology: recent progress and future prospects. J Mar Syst 71:223-236

> Cushing DH (1990) Plankton production and year-class strength in fish populations: an update of the match/mismatch hypothesis. Adv Mar Biol 26:249-293

Dorn M, Aydin K, Barbeaux S, Guttormsen M, Megrey B, Spalinger K, Wilkins M (2008) Gulf of Alaska walleye pollock, In: Stock assessment and fishery evaluation report for the groundfish resources of the Gulf of Alaska. North Pacific Fishery Management Council, Anchorage, AK, p 53-168

Duffy-Anderson JT, Bailey K, Ciannelli L, Cury P, Belgrano A, Stenseth NC (2005) Phase transitions in marine fish recruitment processes. Ecol Complex 2:205-218

Eastwood PD, Meaden GJ, Grioche A (2001) Modeling spatial variations in spawning habitat suitability for the sole Solea solea using regression quantiles and GIS procedures. Mar Ecol Prog Ser 224:251-266

Fromentin JM, Myers RA, Bjornstad ON, Stenseth NC, Gjosaeter J, Christie H (2001) Effects of density-dependent and stochastic processes on the regulation of cod populations. Ecology 82:567-579

Hamatsu T, Yabuki K, Watanabe K (2004) Decadal changes in reproduction of walleye pollock (Theragra chalcogramma) off the Pacific coast of northern Japan. Fish Oceanogr 13(Suppl 1):74-83

Hare SR, Mantua NJ (2000) Empirical evidence for North Pacific regime shifts in 1977 and 1989. Prog Oceanogr 47:103-145

Hastie T, Tibshirani R (1993) Varying-coefficient models. J R Stat Soc B 55:757-796

Hermann AJ, Stabeno PJ (1996) An eddy-resolving model of circulation on the western Gulf of Alaska shelf. 1. Model development and sensitivity analysis. J Geophys Res 101 (C1):1129-1149

Houde ED (1987) Fish early life dynamics and recruitment variability. Am Fish Soc Symp 2:17-29

Hsieh CH, Kim HJ, Watson W, Di Lorenzo E, Sugihara G (2009) Climate-driven changes in abundance and distribution of larvae of oceanic fishes in the southern California region. Global Change Biol 15:2137-2152

Iles TD, Sinclair M (1982) Atlantic herring — stock discreteness and abundance. Science 215:627-633

Kendall AW, Picquelle SJ (1990) Egg and larval distributions of walleye pollock Theragra chalcogramma in Shelikof Strait, Gulf of Alaska. Fish Bull (Wash DC) 88:133-154

Kendall AW, Clarke ME, Yoklavich MM, Boehlert GW (1987) Distribution, feeding, and growth of larval walleye pollock, Theragra chalcogramma, from Shelikof Strait, Gulf

Editorial responsibility: Jake Rice,

Ottawa, Canada of Alaska. Fish Bull (Wash DC) 85:499-521

> Kendall AW, Schumacher JD, Kim S (1996) Walleye pollock recruitment in Shelikof Strait: applied fisheries oceanography. Fish Oceanogr 5:4-18

Leggett WC, DeBlois E (1994) Recruitment in marine fishes: Is it regulated by starvation and predation in the egg and larval stages? Neth J Sea Res 32:119-134

MacCall AD (1990) Dynamic geography of marine fish populations. University of Washington Press, Seattle, WA

MacKenzie BR, Köster FW (2004) Fish production and climate: sprat in the Baltic Sea. Ecology 85:784-794

Matarese AC, Blood DM, Picquelle SJ, Benson JL (2003) Atlas of abundance and distribution patterns of ichthyoplankton from the northeast Pacific Ocean and Bering Sea ecosystems based on research conducted by the Alaska Fisheries Science Center (1972-1996). NOAA Prof Pap NMFS No. 1, NOAA, Seattle, WA

Megrey BM, Hollowed AB, Hare SR, Macklin SA, Stabeno PJ (1996) Contributions of FOCI research to forecasts of yearclass strength of walleye pollock in Shelikof Strait, Alaska. Fish Oceanogr 5(Suppl 1):189-203

> Myers RA (1998) When do environment-recruitment correlations work? Rev Fish Biol Fish 8:285-305

Myers RA, Stokes K (1989) Density-dependent habitat utilization of groundfish and the improvement of research surveys. ICES/Comm Meet D15:1-11

Park YS, Sakurai Y, Iida K, Sano N (1994) Sound production related to the reproductive behavior of captive walleye pollock Theragra chalcogramma (Pallas). Nippon Suisan Gakkai Shi 60:467-472

Pennington M (1983) Efficient estimators of abundance for fish and plankton surveys. Biometrics 39:281-286

> Petitgas P (1998) Biomass-dependent dynamics of fish spatial distributions characterized by geostatistical aggregation curves. ICES J Mar Sci 55:443-453

R Development Core Team (2008) R: a language and environment for statistical computing. R Foundation for Statistical Computing, Vienna

> Sadovy Y, Domeier M (2005) Are aggregation-fisheries sustainable? Reef fish fisheries as a case study. Coral Reefs 24:254-262

Shepherd TD, Litvak MK (2004) Density-dependent habitat selection and the ideal free distribution in marine fish spatial dynamics: considerations and cautions. Fish Fish 5: 141-152

Stefánsson G, Pálsson OK (1997) Statistical evaluation and modeling of the stomach contents of Icelandic cod (Gadus morhua). Can J Fish Aquat Sci 54:169-181

Stenseth NC, Bjørnstad ON, Falck W, Fromentin JM, Gjoesaeter J, Gray JS (1999) Dynamics of coastal cod populations: intra- and inter-cohort density dependence and stochastic processes. Proc R Soc Lond B Biol Sci 266:1645-1654

Swain DP, Wade EJ (1993) Density-dependent geographic distribution of Atlantic cod (Gadus morhua) in the southern Gulf of St. Lawrence. Can J Fish Aquat Sci 50: 1255-1264

Watanabe Y, Zenitani H, Kimura R (1997) Variations in spawning ground area and egg density of the Japanese sardine in Pacific coastal and oceanic waters. Fish Oceanogr 6:35-40

Wood SN (2004) Stable and efficient multiple smoothing parameter estimation for generalized additive models. J Am Stat Assoc 99:673-686

Wood SN (2006) Generalized additive models: an introduction with R. Chapman \& Hall/CRC, Boca Raton, FL

Submitted: June 21, 2009; Accepted: August 5, 2009

Proofs received from author(s): September 16, 2009 